\title{
Pathogen Burden, Inflammation, Proliferation and Apoptosis in Human In-Stent Restenosis
}

\author{
Tissue Characteristics Compared to Primary Atherosclerosis
}

\author{
Dirk Skowasch $^{\text {a }}$ Alexander Jabs ${ }^{a}$ René Andrié ${ }^{a}$ Sabine Dinkelbach ${ }^{a}$ \\ Thomas M. Schiele ${ }^{b}$ Nicolas Wernert ${ }^{c}$ Berndt Lüderitz ${ }^{a}$ \\ Gerhard Bauriedela
}

aDepartment of Cardiology, University of Bonn, Bonn; ${ }^{\text {CC}}$ Cardiology Division, University of Munich, Munich, and

cInstitute of Pathology, University of Bonn, Bonn, Germany

\section{Key Words}

Apoptosis · Infection • Inflammation • Proliferation •

In-stent restenosis $\cdot$ Stents

\begin{abstract}
Pathogenic events leading to in-stent restenosis (ISR) are still incompletely understood. Among others, inflammation, immune reactions, deregulated cell death and growth have been suggested. Therefore, atherectomy probes from 21 patients with symptomatic ISR were analyzed by immunohistochemistry for pathogen burden and compared to primary target lesions from 20 stable angina patients. While cytomegalovirus, herpes simplex virus, Epstein-Barr virus and Helicobacter pylori were not found in ISR, acute and/or persistent chlamydial infection were present in 6/21 of these lesions (29\%). Expression of human heat shock protein 60 was found in 8/21 of probes (38\%). Indicated by distinct signals of CD68, CD40 and CRP, inflammation was present in 5/21 (24\%), 3/21 $(14 \%)$ and $2 / 21(10 \%)$ of ISR cases. Cell density of ISR was significantly higher than that of primary lesions (977 \pm 315 vs. $431 \pm 148$ cells $\left./ \mathrm{mm}^{2} ; \mathrm{p}<0.001\right)$. There was no replicating cell as shown by Ki67 or PCNA. TUNEL ${ }^{+}$cells
\end{abstract}

indicating apoptosis were seen in 6/21 of ISR specimens (29\%). Quantitative analysis revealed lower expression levels for each intimal determinant in ISR compared to primary atheroma (all $p<0.05$ ). In summary, human ISR at the time of clinical presentation is characterized by low frequency of pathogen burden and inflammation, but pronounced hypercellularity, low apoptosis and absence of proliferation.

Copyright @ 2004 S. Karger AG, Basel

\section{Introduction}

Coronary stent implantation is widely accepted as a modality to prevent restenosis. However, intimal hyperplasia leading to in-stent restenosis (ISR) markedly limits the long-term success of stenting by pathobiological events that are still poorly understood $[1,2]$. While atherosclerosis is now regarded as a chronic inflammatory disease in response to injury [3], ISR events in patients has only been studied by a few reports dealing with atherectomy probes [4-7] or post mortem tissue samples [8$11]$.

\begin{tabular}{ll}
\hline KARGER & ( 2004 S. Karger AG, Basel \\
1018-1172/04/0416-0525\$21.00/0 \\
$\begin{array}{l}\text { Fax +4161306 12 34 } \\
\begin{array}{l}\text { E-Mail karger@karger.ch } \\
\text { www.karger.com }\end{array}\end{array}$ & $\begin{array}{l}\text { Accessible online at: } \\
\text { www.karger.com/jvr }\end{array}$
\end{tabular}

Dirk Skowasch, MD; Gerhard Bauriedel, MD

Department of Cardiology, University of Bonn

Sigmund-Freud-Strasse 25

DE-53105 Bonn (Germany)

Tel. +49 228/287 6670, Fax +49 228/287 4983, E-Mail Dirk.Skowasch@ukb.uni-bonn.de 
Several groups reported macrophages accumulated adjacent to stent struts, suggesting that vascular wall injury and/or stent material elicit inflammatory reactions [5, 813]. In addition, infections with various bacterial and viral pathogens have been associated with atherosclerotic disease [3, 14]. Initial steps in atherosclerosis may result from the direct cytopathic effect of the pathogen that replicates in the vascular wall, or may be mediated by an immune response directed against cellular antigens. As suggested, chronic immune-mediated inflammatory responses in atherosclerosis may be antigen-specific and directed against autoantigens or pathogen-derived structures [3]. Although possible associations between restenosis with specific infectious agents have been proposed by seroepidemiological studies that focused on cytomegalovirus (CMV), Chlamydia pneumoniae and intimal pathogen burden [15-20], to our knowledge, its presence in ISR lesions has not yet been determined. Likewise, with regard to the regulation of neointimal cellularity in clinical restenosis, proliferative activity of smooth muscle cells remains controversial [21, 22], whereas low levels of intimal apoptosis post-balloon angioplasty compared to primary atheroma were previously reported by our group [23]. Therefore, the present study was designed to systematically examine the extent of neointimal pathogen burden, inflammation, proliferation and apoptosis in symptomatic human ISR atherectomy probes.

\section{Methods}

\section{Patients and Arterial Specimens}

A series of 41 symptomatic patients ( 34 men and 7 women; mean age $58 \pm 9$ years) had been percutaneously treated by directional atherectomy (Danimed, Isernhagen, Germany) [24, 25]. A total of 41 atherectomy probes were obtained, including 21 ISR lesions ( 13 coronary, 7 peripheral), and 20 primary coronary lesions from patients with stable angina (table 1). All patients received heparin intravenously 30-60 min before and during the procedure. All patients had given informed consent for subsequent analysis of excised plaque tissue, and tissue collection was carried out under institutional Ethics Committee-approved protocols.

\section{Immunohistochemistry}

Tissue samples were fixed in $4.5 \%$ buffered formaldehyde and embedded in paraffin. Serial sections $(4 \mu \mathrm{m})$ were dewaxed and rehydrated. After retrieval with $95^{\circ} \mathrm{C}$ citrate buffer $(8 \mathrm{~min}, 3 \%)$, tissue segments were incubated with rabbit serum (Dianova, Hamburg, Germany, dilution 1:5), to block nonspecific binding sites. Sections were treated with monoclonal anti- $\alpha$-smooth muscle actin (clone 1A4, Sigma, Deisenhofen, Germany, 1:250), anti-CMV (clone CCH, Dako, Hamburg, Germany, 1:10), anti-major outer membrane protein (MOMP; clone RR402, Dako, 1:100), anti-chlamydial HSP60 (clone A57-B9, Dianova, 1:250), anti-human HSP60 (clone 4Bo/89,
Dianova, 1:250), anti-CD68 (clone KP1, Dako, 1:100), anti-CD40 (clone B-B20, Dianova, 1:250) or anti-proliferation cell nuclear antigene (PCNA; clone PC10, Becton Dickinson, Leiden, Netherlands, $1: 10$ ). For the polyclonal rabbit anti-CRP antibody (catalog no 68206, ICN-Biomedicals, Aurora, Ohio, USA, 1:250), retrieval was performed with saponine (2\%) and incubation with FCS (1:25) was applied for $30 \mathrm{~min}$ at room temperature following primary antibody incubation. The final reaction product was stained with the APAAP kit (Dianova) and Fast Red (Sigma) as chromogen, according to standard protocols. Ki67 staining experiments were performed using the avidin-biotin method: Briefly, after the inhibition of endogenous peroxidase activity with methanol and hydrogen peroxide (3\%) and predigestion with $95^{\circ} \mathrm{C}$ citrate buffer, nonspecific binding sites were blocked by normal goat serum (Dianova, 1:10). Sections were then incubated with the Ki67 antibody (clone MIB-1, Dako, 1:100) for $40 \mathrm{~min}$ at $37^{\circ} \mathrm{C}$. Antibody binding was visualized with a biotinylated goat antimouse antibody (Vector, Grünberg, Germany, 1:50), followed by the ABC complex (Vector) and aminoethylcarbazole (ICN, Eschwege, Germany) as chromogen. Nuclear counterstaining was done by hematoxylin.

The terminal deoxynucleotidyl transferase (Tdt)-mediated TUNEL test (in situ cell death detection kit, AP, Boehringer Mannheim, Germany) was used according to the manufacturer's directions and as described previously [23]. Herein, Tdt catalyzes the binding of fluorescein-labeled nucleotides to free $3^{\prime}$-hydroxyl DNA ends in a template-independent manner, thereby labeling DNA strand breaks. Antifluorescein antibody sheep Fab fragments conjugated with alkaline phosphatase were then used for former strand break detection. Positive and negative controls were run with each test series: mammalian epithelial cells infected with Chlamydia pneumoniae (Medac, Hamburg, Germany), lung tissue infected with CMV (Dako), carotid arteries, tissues from a non-Hodgkin lymphoma for Ki67 and from tonsil for TUNEL analysis served as positive controls. Negative controls included omission of the antibodies staining with unspecific antibody (mouse monoclonal IgG1, clone NCG01, Dianova and ChromPure rabbit IgG, code number 011-000-003, Dianova, respectively) in the same concentrations as the primary antibodies as well as tissue samples taken from nonimplanted saphenous vein grafts and normal mammary arteries. Negative controls for TUNEL included omission of Tdt.

Morphometric analysis was done by use of a computer-assisted morphometry system (VFG 1 graphic card/VIBAM 0.0. software). Pictures were obtained with an Optiphot-2 microscope (Nikon, Düsseldorf, Germany) and a KP-C553CCD video camera (Hitachi, Rodgau, Germany). Morphometric data were evaluated in five randomly selected areas $\left(0.04 \mathrm{~mm}^{2}\right.$ each $)$ per cross-section by two independent examiners.

\section{Statistical Analysis}

Data are reported as presence (percentage of determinant-positive lesions per total number of lesions) and expression [percentage (mean \pm SEM) of stained cells per total number of cells]. We assessed group differences by the use of $\chi^{2}$ test for categorical variables. Probability was calculated with the Mann-Whitney U test for differences in cell density and expression of intimal determinants. Correlation coefficients were determined by Pearson's test. $p$ values of $<0.05$ were considered to denote statistical significance. 
Table 1. Patients and lesion characteristics

\begin{tabular}{|c|c|c|c|c|c|c|c|}
\hline No. & Age & Gender & Risk factors & Medication & $\begin{array}{l}\text { Treated } \\
\text { vessel }\end{array}$ & $\begin{array}{l}\text { Number/weight } \\
\text { of plaques, mg }\end{array}$ & $\begin{array}{l}\text { Time interval } \\
\text { months }\end{array}$ \\
\hline \multicolumn{8}{|c|}{ In-stent restenosis } \\
\hline 1 & 45 & $\mathrm{M}$ & $\mathrm{F}, \mathrm{L}$ & $\mathrm{Lm}$ & LAD & $9 / 56$ & 2 \\
\hline 2 & 45 & M & $\mathrm{F}, \mathrm{L}$ & $\mathrm{Lm}$ & $\mathrm{RCx}$ & $4 / 17$ & 10 \\
\hline 3 & 54 & M & $\mathrm{O}$ & ACE, Be, Lm, Ni, As & $\mathrm{RCA}$ & $3 / 16$ & 6 \\
\hline 4 & 44 & $\mathrm{~F}$ & $\mathrm{~L}, \mathrm{O}, \mathrm{N}$ & $\mathrm{Be}, \mathrm{Lm}, \mathrm{As}$ & $\mathrm{RCA}$ & $1 / 5$ & 5 \\
\hline 5 & 58 & M & $\mathrm{H}, \mathrm{L}, \mathrm{F}$ & $\mathrm{Be}, \mathrm{As}$ & LAD & $2 / 12$ & 6 \\
\hline 6 & 49 & M & $\mathrm{L}, \mathrm{N}$ & ACE, Be, Lm, Ni, As & LAD & $3 / 16$ & 4 \\
\hline 7 & 65 & $\mathrm{~F}$ & $\mathrm{H}, \mathrm{L}$ & $\mathrm{Lm}, \mathrm{Ni}, \mathrm{As}$ & Bypass & $4 / 19$ & 3 \\
\hline 8 & 77 & $\mathrm{M}$ & $\mathrm{D}, \mathrm{L}$ & ACE, Lm, As & RCA & $5 / 25$ & 5 \\
\hline 9 & 60 & $\mathrm{M}$ & $\mathrm{D}, \mathrm{H}, \mathrm{L}$ & $\mathrm{ACE}, \mathrm{Be}, \mathrm{Ca}, \mathrm{Lm}, \mathrm{As}$ & LAD & $5 / 39$ & 6 \\
\hline 10 & 71 & $\mathrm{~F}$ & $\mathrm{D}, \mathrm{H}, \mathrm{L}, \mathrm{O}$ & $\mathrm{Be}, \mathrm{Ca}, \mathrm{Lm}, \mathrm{Ni}, \mathrm{As}$ & Bypass & $3 / 17$ & 12 \\
\hline 11 & 54 & M & $\mathrm{D}, \mathrm{H}, \mathrm{L}$ & $\mathrm{ACE}, \mathrm{Be}, \mathrm{Lm}, \mathrm{As}$ & $\mathrm{RCx}$ & $3 / 10$ & 7 \\
\hline 12 & 66 & M & $\mathrm{D}, \mathrm{L}$ & $\mathrm{Lm}$ & $\mathrm{RCA}$ & $1 / 5$ & 5 \\
\hline 13 & 58 & $\mathrm{~F}$ & $\mathrm{H}, \mathrm{L}, \mathrm{F}$ & $\mathrm{Be}, \mathrm{As}$ & LAD & $4 / 26$ & 6 \\
\hline 14 & 56 & M & $\mathrm{L}, \mathrm{O}, \mathrm{N}$ & Lm, As & $\mathrm{RCA}$ & $2 / 13$ & 6 \\
\hline 15 & 74 & $\mathrm{~F}$ & $\mathrm{H}, \mathrm{L}, \mathrm{N}$ & ACE, Ca, Lm, As & SFA & $5 / 63$ & 6 \\
\hline 16 & 45 & M & $\mathrm{L}, \mathrm{N}$ & $\mathrm{Lm}, \mathrm{As}$ & SFA & $4 / 29$ & 6 \\
\hline 17 & 60 & M & $\mathrm{H}, \mathrm{L}, \mathrm{N}$ & $\mathrm{ACE}, \mathrm{Be}, \mathrm{Lm}, \mathrm{As}$ & SFA & $8 / 132$ & 4 \\
\hline 18 & 60 & $\mathrm{M}$ & $\mathrm{D}, \mathrm{O}$ & $\mathrm{Ca}, \mathrm{As}$ & SFA & $9 / 167$ & 3 \\
\hline 19 & 72 & M & $\mathrm{D}, \mathrm{H}$ & $\mathrm{Lm}, \mathrm{Ni}, \mathrm{As}$ & SFA & $3 / 54$ & 6 \\
\hline 20 & 60 & $\mathrm{M}$ & $\mathrm{D}$ & ACE, Lm, Ni, As & SFA & $4 / 66$ & 12 \\
\hline 21 & 46 & $\mathrm{M}$ & $\mathrm{H}, \mathrm{L}, \mathrm{N}$ & $\mathrm{Lm}, \mathrm{As}$ & IA & $7 / 86$ & 10 \\
\hline \multicolumn{8}{|c|}{ De novo lesions } \\
\hline 1 & 62 & $\mathrm{~F}$ & $\mathrm{~L}, \mathrm{~N}$ & $\mathrm{ACE}, \mathrm{Be}, \mathrm{Ni}, \mathrm{As}$ & $\mathrm{RCx}$ & $3 / 20$ & \\
\hline 2 & 69 & M & $\mathrm{L}$ & $\mathrm{Be}, \mathrm{Ca}, \mathrm{Lm}, \mathrm{Ni}, \mathrm{As}$ & LAD & $3 / 11$ & \\
\hline 3 & 61 & M & $\mathrm{H}, \mathrm{O}, \mathrm{N}$ & $\mathrm{Ni}$ & $\mathrm{RCA}$ & $1 / 3$ & \\
\hline 4 & 62 & $\mathrm{~F}$ & $\mathrm{H}$ & $\mathrm{ACE}, \mathrm{Ca}, \mathrm{Ni}, \mathrm{As}$ & RCA & $2 / 6$ & \\
\hline 5 & 50 & $\mathrm{M}$ & $\mathrm{L}, \mathrm{F}$ & $\mathrm{Be}, \mathrm{Lm}, \mathrm{Ni}, \mathrm{As}$ & LAD & $5 / 12$ & \\
\hline 6 & 53 & M & $\mathrm{H}, \mathrm{L}, \mathrm{F}$ & $\mathrm{ACE}, \mathrm{Be}, \mathrm{Ca}, \mathrm{Lm}, \mathrm{As}$ & $\mathrm{RCA}$ & $4 / 9$ & \\
\hline 7 & 66 & M & $\mathrm{L}$ & $\mathrm{Lm}, \mathrm{Ni}$ & RCA & $9 / 40$ & \\
\hline 8 & 50 & M & $\mathrm{L}, \mathrm{O}, \mathrm{F}$ & $\mathrm{Lm}$ & LAD & $7 / 45$ & \\
\hline 9 & 59 & $\mathrm{M}$ & $\mathrm{L}$ & $\mathrm{Be}, \mathrm{Ni}, \mathrm{As}$ & LAD & $8 / 49$ & \\
\hline 10 & 48 & M & $\mathrm{N}$ & $\mathrm{Ni}$ & LAD & $5 / 35$ & \\
\hline 11 & 66 & M & $\mathrm{D}, \mathrm{H}, \mathrm{F}$ & $\mathrm{Be}, \mathrm{Ni}, \mathrm{As}$ & LAD & $7 / 32$ & \\
\hline 12 & 63 & M & $\mathrm{F}$ & $\mathrm{Ni}, \mathrm{As}$ & $\mathrm{RCA}$ & $1 / 8$ & \\
\hline 13 & 61 & $\mathrm{M}$ & $\mathrm{H}$ & $\mathrm{ACE}, \mathrm{Be}, \mathrm{Lm}, \mathrm{Ni}, \mathrm{As}$ & LAD & $7 / 28$ & \\
\hline 14 & 51 & $\mathrm{M}$ & $\mathrm{L}, \mathrm{F}, \mathrm{N}$ & $\mathrm{ACE}, \mathrm{Ca}, \mathrm{Lm}, \mathrm{Ni}$ & LAD & $3 / 8$ & \\
\hline 15 & 62 & $\mathrm{M}$ & $\mathrm{L}, \mathrm{F}$ & $\mathrm{ACE}, \mathrm{Ni}$ & RCA & $4 / 13$ & \\
\hline 16 & 69 & M & $\mathrm{O}$ & As & LAD & $4 / 19$ & \\
\hline 17 & 43 & $\mathrm{M}$ & $\mathrm{H}, \mathrm{L}, \mathrm{N}$ & $\mathrm{Ca}, \mathrm{Ni}, \mathrm{As}$ & LAD & $8 / 41$ & \\
\hline 18 & 48 & M & $\mathrm{L}$ & $\mathrm{ACE}, \mathrm{Ni}, \mathrm{As}$ & LAD & $4 / 16$ & \\
\hline 19 & 62 & $\mathrm{M}$ & $\mathrm{H}, \mathrm{O}$ & As, Lm & LAD & $5 / 12$ & \\
\hline 20 & 62 & $\mathrm{M}$ & $\mathrm{H}, \mathrm{L}, \mathrm{F}$ & $\mathrm{ACE}, \mathrm{Ca}, \mathrm{Lm}, \mathrm{As}$ & LAD & $2 / 6$ & \\
\hline
\end{tabular}

LAD = Left anterior descending; $\mathrm{RCx}=$ Ramus circumflexus; $\mathrm{RCA}=$ right coronary artery; SFA = superficial femoral artery; IA = iliac artery; $\mathrm{D}=$ diabetes mellitus; $\mathrm{H}=$ hypertension; $\mathrm{L}=$ hyperlipidemia; $\mathrm{F}=$ familiar disposition; $\mathrm{N}=$ nicotine; $\mathrm{O}=$ obesity; $\mathrm{ACE}=$ ace inhibitor; $\mathrm{Be}=\beta$-blocker $\mathrm{Ca}=$ calcium antagonist; $\mathrm{Lm}=$ antilipid medication; $\mathrm{Ni}=$ nitrate; $\mathrm{As}=$ aspirin. 
Table 2. Coronary and peripheral ISR samples: lesion characteristics

\begin{tabular}{rrllllll}
\hline \multirow{2}{*}{ No. } & Cells $/ \mathrm{mm}^{2}$ & \multicolumn{2}{l}{ Expression, $\%$} & & \\
\cline { 3 - 7 } & & MOMP & cHSP60 & hHSP60 & CD68 & CD40 & CRP \\
\hline 1 & 1,421 & 0 & 0.1 & 0 & 0 & 0 & 0 \\
2 & 1,562 & 0.5 & 0.6 & 0 & 0 & 0 & 0 \\
3 & 984 & 0.2 & 0 & 0 & 0 & 0 & 0 \\
4 & 810 & 0 & 0 & 0.4 & 0 & 0.6 & 0 \\
5 & 1,426 & 0 & 0 & 0 & 0 & 0.8 & 0 \\
6 & 999 & 0 & 0 & 0 & 0 & 0 & 0 \\
7 & 858 & 0 & 0 & 0 & 3.1 & 0 & 0 \\
8 & 1,260 & 0 & 0 & 0 & 0 & 0.6 & 0 \\
9 & 738 & 0.2 & 0 & 0.5 & 0.7 & 0 & 0 \\
10 & 785 & 0 & 0 & 0.1 & 0 & 0 & 0 \\
11 & 762 & 0 & 0 & 0 & 0 & 0 & 0 \\
12 & 1,093 & 0 & 0 & 0 & 0 & 0 & 0 \\
13 & 1,175 & 0 & 0 & 0.6 & 0 & 0 & 0.6 \\
14 & 535 & 0 & 0 & 0.5 & 0.7 & 0 & 0 \\
15 & 394 & 0 & 0.4 & 0.5 & 0 & 0 & 0.3 \\
16 & 645 & 0.3 & 2.4 & 0 & 0 & 0 & 0 \\
17 & 1,437 & 0 & 0 & 0 & 0.3 & 0 & 0 \\
18 & 879 & 0 & 0 & 0 & 0 & 0 & 0 \\
19 & 989 & 1.2 & 8.9 & 18.7 & 0 & 0 & 0 \\
20 & 1,025 & 0 & 0 & 0 & 0.6 & 0 & 0 \\
21 & 737 & 0 & 3.2 & 1.6 & 0 & 0 & 0 \\
\hline$\Sigma$ & $977 \pm 315$ & $0.1 \pm 0.2$ & $0.7 \pm 2.1$ & $1.1 \pm 4.4$ & $0.3 \pm 0.8$ & $0.1 \pm 0.2$ & $0.04 \pm 0.1$ \\
\hline 1 & & & & & & & 0 \\
\hline
\end{tabular}

CMV, HSV, EBV, HP, Ki67 and PCNA were not found in ISR tissue; data are not shown in table 1.

\section{Results}

ISR probes $(\mathrm{n}=21)$ were compared to primary atheroma $(n=20)$ with respect to pathogen burden, inflammation markers, (neo)intimal cellularity, proliferation and apoptosis. Demographics and medication of ISR patients did not differ from those of primary lesion patients (table 1). Comparison of cardiovascular risk factors revealed a higher prevalence only for diabetes in the ISR group $(\mathrm{p}=$ 0.008), but not for hypertension, hyperlipidemia, familial disposition, nicotine or obesity. ISR characteristics and quantitative histopathological data are summarized in table 2. Typical immunohistochemical examples of ISR lesions illustrating the expression pattern of specific key determinants are given in fig. 1-3. Summarized quantitative data resulting from pathological examination of atherectomy tissue are presented in fig. 4 .

\section{Infection/Pathogen Burden}

ISR tissue did not show any signal indicating the presence of CMV (fig. 1a). In contrast, primary lesions re- vealed CMV in 8 of 20 cases (40\%); $2.3 \%$ of intimal cells were positive for CMV (fig. 4). Evidence of Chlamydia pneumoniae, indicated by the presence of chlamydial major outer membrane protein (MOMP) for acute infection and that of chlamydial heat shock protein 60 (cHSP60) for chronic persistent infection, was found in 6/21 of the ISR lesions (29\%; fig. 1b), for each marker. Presence of the human HSP60 homolog (hHSP60) was seen in 8/21 ISR cases (38\%; fig. 1c). In addition, lesions showed low expression levels of Chlamydia-associated determinants of $<1 \%$ (table 1, fig. 4). In contrast, primary lesions revealed immunoreaction in 11/20 (55\%) of all cases for MOMP, 12/20 (60\%) for cHSP60 and 13/20 (65\%) for hHSP60, as well as significantly higher lesional expression levels (fig. 4). While herpes simplex virus (HSV), Epstein Barr virus (EBV) and Helicobacter pylori (HP) were not present in any ISR sample, the percentage of immunolabeled cells for each of these infectious pathogens was higher in primary lesions (fig. 4). Whenever markers of infectious agents were observed, they were not confined to particular plaque regions or predilection sites. 

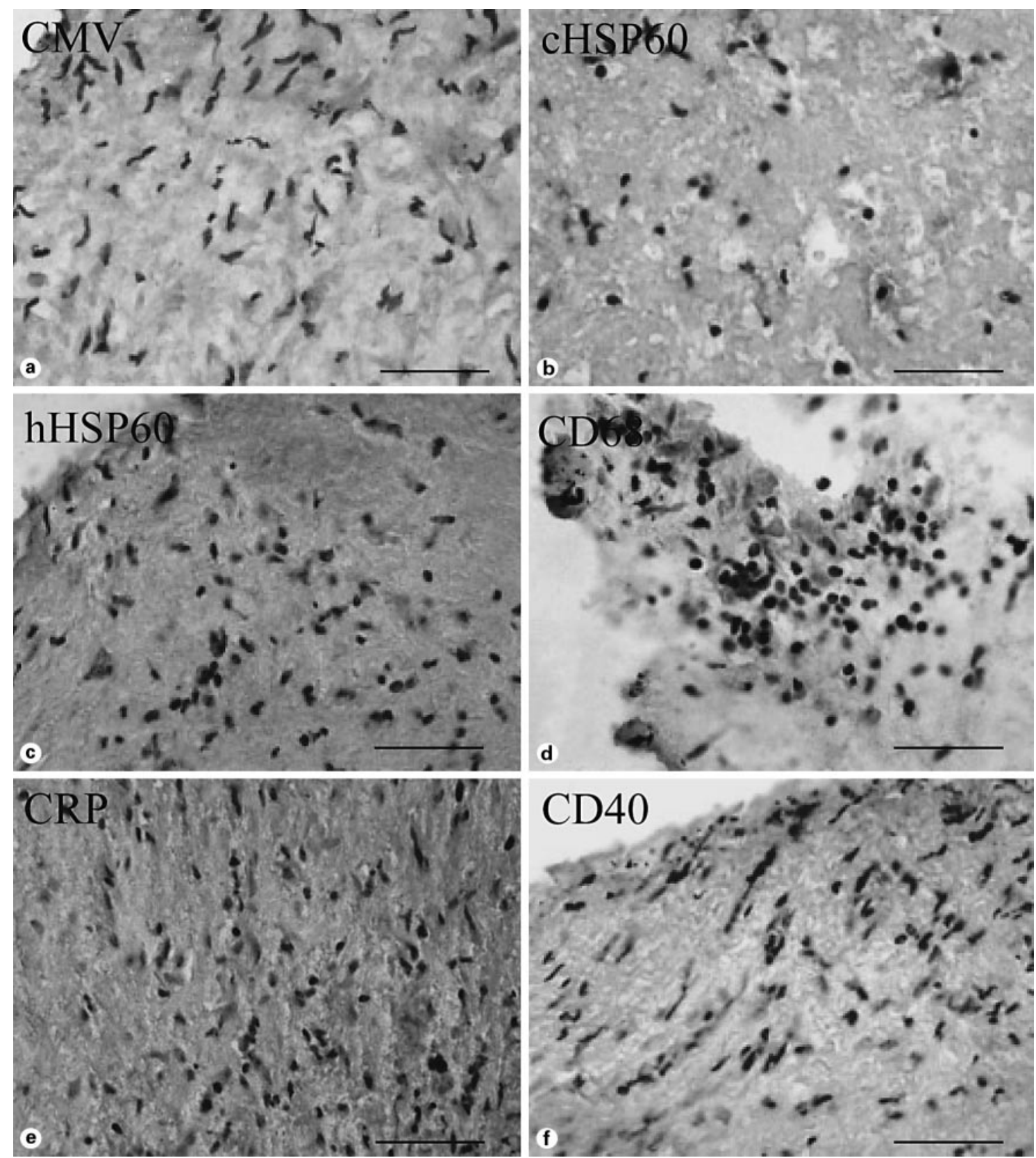

Fig. 1. Photomicrographs of representative ISR lesions that demonstrate homogeneous hypercellularity (a) without CMV presence, (b) with sparse signaling of cHSP60 indicative of chronic persistent chlamydial infections, (c) with sparse immunostaining of the human HSP60 homolog, (d) with infrequent cell-bound signals of macrophages, (e) without CRP expression, (f) with sparse CD40 immunoreactivity; thereby providing evidence for lack of infection and inflammation in clinical ISR; bar $=50 \mu \mathrm{m}$.

\section{Inflammation}

Presence (24\%) and expression (0.3\%) of CD68+ macrophages was markedly lower in ISR neointima (fig. 1d), compared to $60 \%$ of primary lesions (fig. 2 d) with CD68 expression in an average of $4.4 \%$ of the lesional cells $(\mathrm{p}=$
0.003; fig. 4). However, in one case, focal aggregation of macrophages was observed, suggesting adjacent stent material in vivo. Similar to CD68, both CD40 and CRP were sparse in $3 / 21(14 \%)$ and $2 / 21$ ISR lesions $(10 \%)$, whereas the same markers were present in $10 / 20(50 \%)$ and $12 / 20$ 

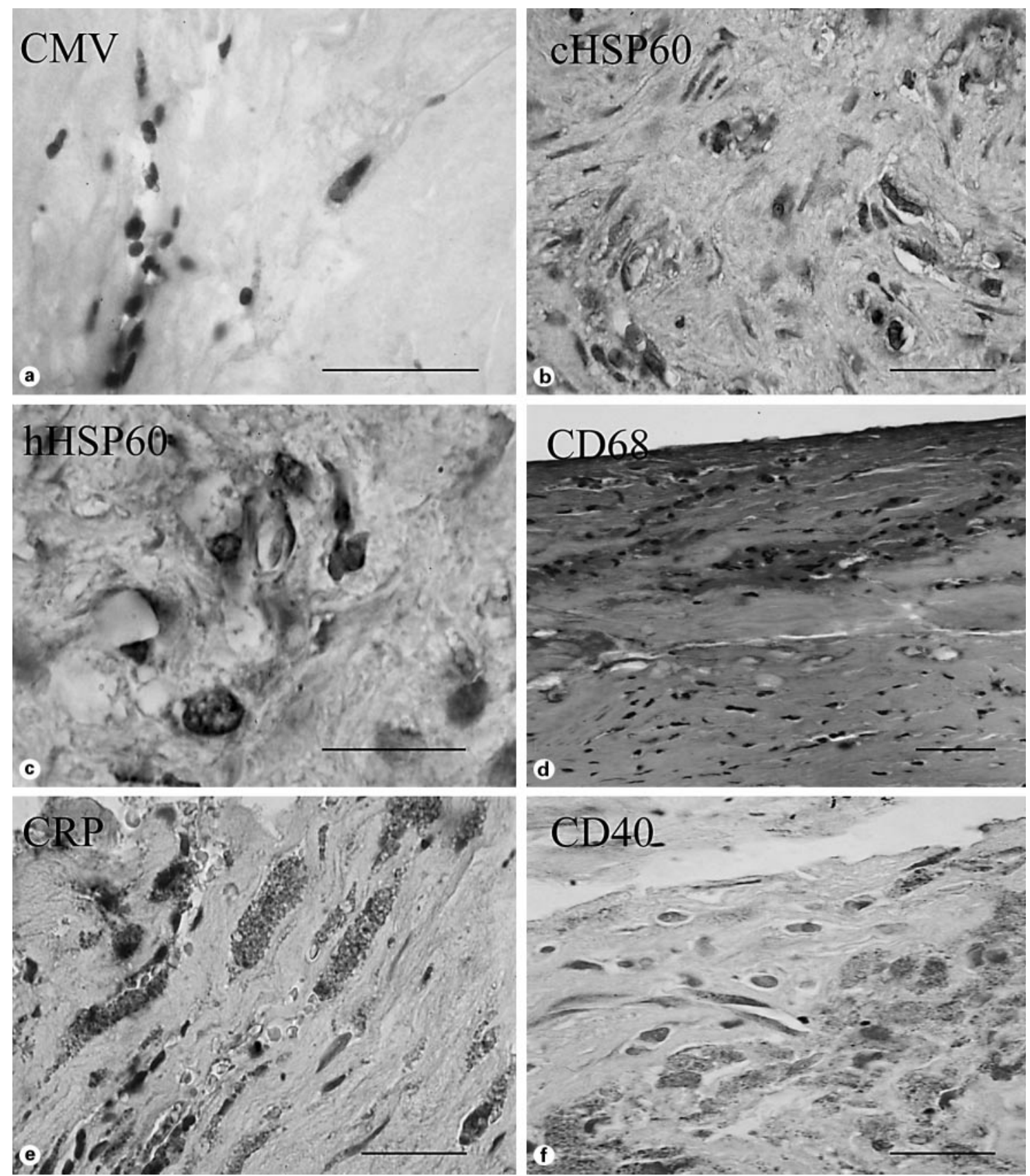

Fig. 2. Photomicrographs of primay coronary lesions from patients with stable angina. Typical intimal localization of (a) CMV, (b) cHSP60, (c) hHSP60, (d) CD68, (e) CRP and (f) CD40. Note that primary atheroma reveal significantly higher intimal expression of these infectious and inflammatory determinants compared to ISR (fig. 1); bar = $50 \mu \mathrm{m}$.

(60\%), respectively, of primary lesions (fig. 4). Quantitatively, pathogen burden indicated by the number of microorganisms present and expression of CRP correlated significantly $(\mathrm{r}=0.56, \mathrm{p}<0.01)$.

\section{Proliferation, Apoptosis}

ISR probes consistently showed marked hypercellularity compared to primary lesions $(977 \pm 315$ vs. $431 \pm$ 148 cells $\left./ \mathrm{mm}^{2} ; \mathrm{p}<0.001\right)$. The majority of all cells in ISR expressed $\alpha$-smooth muscle actin $(68 \pm 14 \%)$. Despite 
this pronounced cellularity in ISR lesions, there was no evidence of ongoing proliferation in these specimens, as indicated by Ki67 (fig. 3a). In contrast, Ki67 was observed in $19 / 20(95 \%)$ primary lesions, yielding a mean expression of $1.9 \%$. Additional experiments using PCNA antibodies to assess cellular proliferation rates confirmed the lack of cell replication in ISR specimens. Signals of DNA strand breaks indicative for apoptosis were present in 6/21 ISR lesions (29\%; fig. 3c) and demonstrated a markedly lower percentage of TUNEL-positive cells in ISR versus primary lesions $(1.2 \%$ vs. $12.0 \%$; $<<0.001)$.

Interestingly, there was no significant difference between the cellularity in ISR tissue from coronary or peripheral vascular bed $(1,034 \pm 275$ vs. $863 \pm 380$ cells/ $\mathrm{mm}^{2}, \mathrm{p}=0.32$ ) as well as between the expression profiles of other studied markers. In addition, there was no relationship of either cellularity or expression of each studied determinant and the time course after stent implantation.

\section{Discussion}

The present study analyzed pathogen burden, inflammation, proliferation and apoptosis in human ISR atherectomy probes versus primary atherosclerotic coronary lesions. As the main finding, we herein demonstrate a remarkably low frequency of both viruses and bacteria within ISR lesions and thereby, were unable to show a correlation between pathogen burden and ISR (fig. 1 and 4). Given the absence of both CMV and proliferation in neointimal lesions (fig. 1a, 3a), previous suggestions of CMV-dependent pathomechanisms in neointimal hyperplasia due to inhibition of proapoptotic p53 [19] are not supported by our current findings. While these authors reported that prior CMV infection increased the risk of restenosis after directional atherectomy [19], others found no correlation between previous CMV infection and increased risk of restenosis after stenting [16]. As to Chlamydia pneumoniae, we report acute infection (MOMP) and chronic persistence (cHSP60, fig. 1b) of this microorganism in 29\%, and corresponding human HSP60 (hHSP60, fig. 1c) in 38\% of all ISR samples. Autoimmune responses initiated by cross-reactions between microorganism HSP and cellular self-components have been implicated in atherogenesis [14, 18, 20, 26]. However, low presence and expression levels of MOMP and cHSP60/ hHSP60 in ISR (fig. 1b, c) compared to primary lesions (fig. 2c) suggest a negligible role of these determinants in late neointima formation, if at all present. This may also

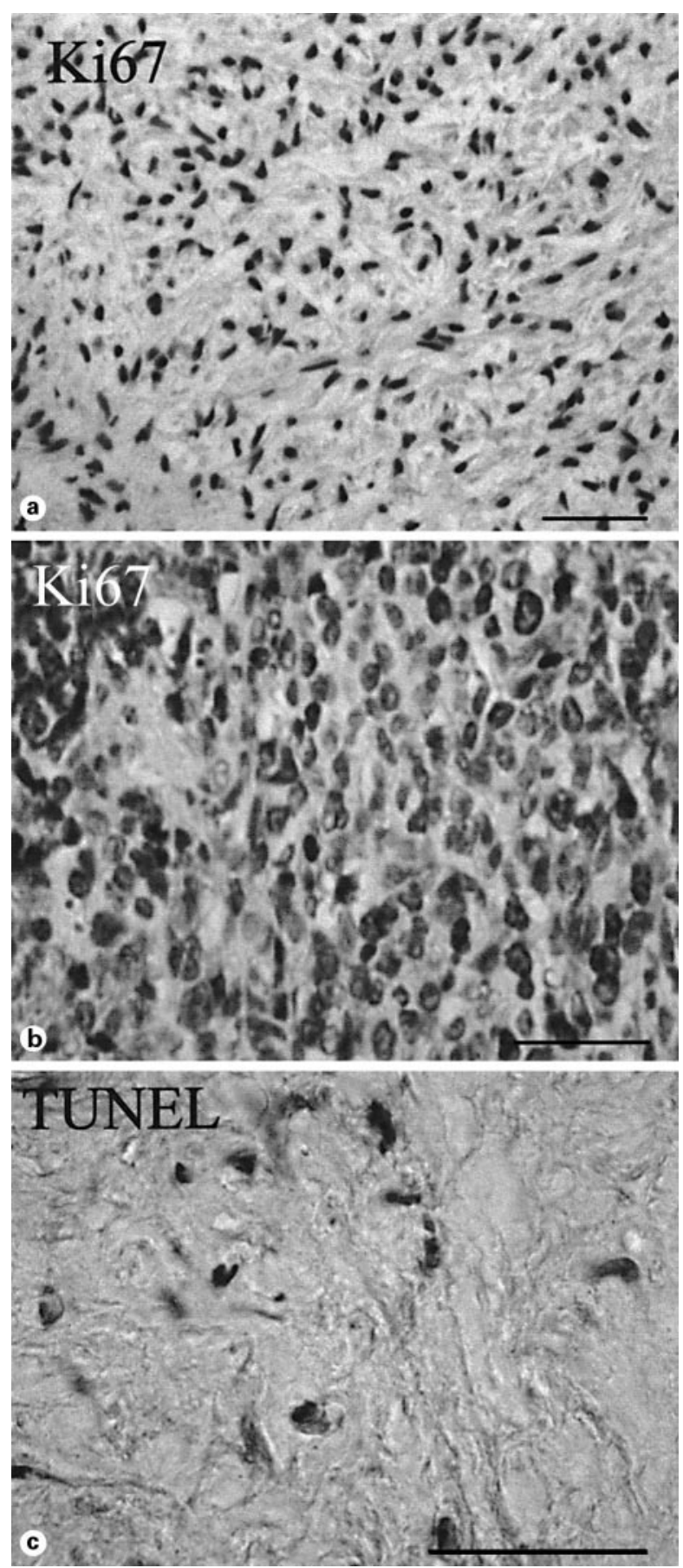

Fig. 3. Representative photomicrographs of in-stent restenosis (ISR) tissue obtained from the left anterior descending of a 60-year-old patient 6 months after stent implantation (a, c, d). a ISR lesion that exhibits no Ki67 $7^{+}$cells. b Positive control of human non-Hodgkin lymphoma containing many $\mathrm{Ki}^{+}{ }^{+}$stained nuclei that indicate ongoing proliferation. c ISR lesion from the same patient that shows a low percentage of TUNEL ${ }^{+}$cells. Of note, parts of media or adventitia were not found in any ISR specimen. Bar $=50 \mu \mathrm{m}$. 
Fig. 4. Presence and expression of pathogen burden (CMV, cytomegalovirus, MOMP, chlamydial major outer membrane protein, cHSP60, chlamydial heat shock protein 60 , hHSP60, human heat shock protein 60, HSV, Herpes simplex virus, EBV, Epstein Barr virus, HP, Helicobacter pylori), inflammation (CD68, macrophages, CD40; CRP, $\mathrm{C}$-reactive protein) and proliferation (Ki-67) was significantly lower in 21 ISR (ם) versus 20 primary lesions $(\square){ }^{*} \mathrm{p}<0.05,{ }^{* *} \mathrm{p}<$ 0.001 .
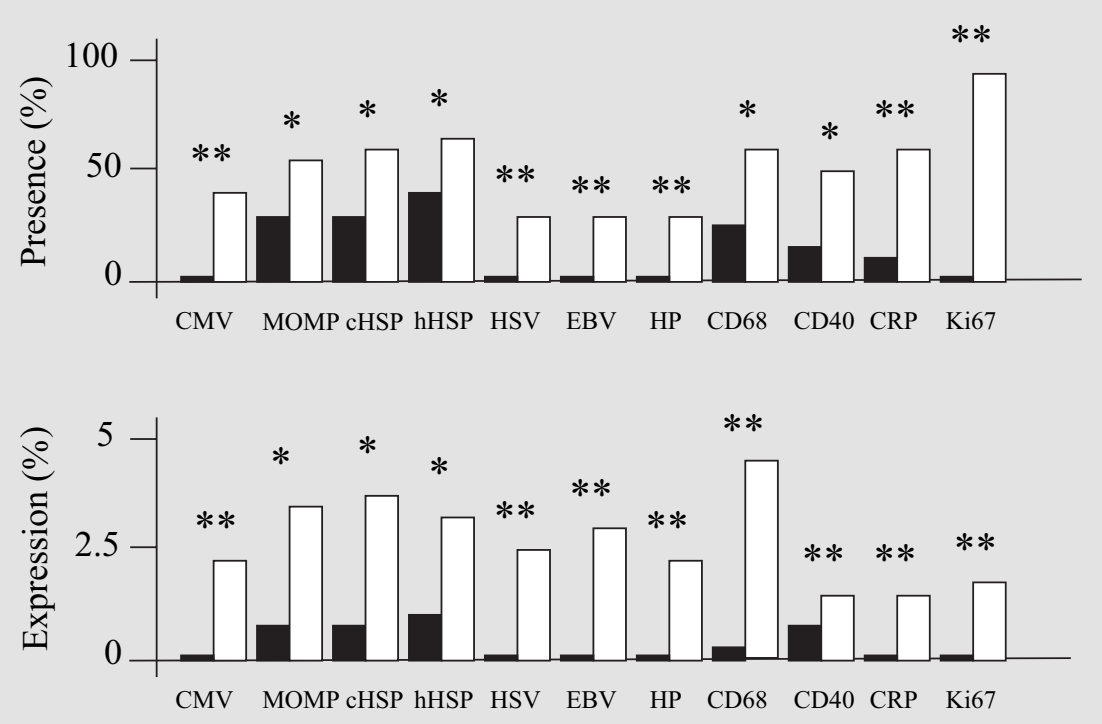

explain the poor clinical outcome within recent antibiotic trials to mitigate ISR [17]. Likewise, neither herpes simplex virus, Epstein-Barr virus nor Helicobacter pylori, infectious pathogens implicated in certain cardiovascular diseases [15, 20, 27], were found in ISR probes removed from symptomatic patients.

In the present study, a few, if any, cells in ISR probes were macrophages (fig. 1d). Since inflammatory cells are commonly found in plaques from patients with acute coronary syndromes $[12,28]$, we exclusively studied coronary primary atheroma associated with stable angina as controls. Recent autopsy studies early post-stent implantation described macrophage accumulations near stent struts [8-10], and thereby suggested the importance of inflammatory reactions also in neointima formation. Farb et al. [13] found a correlation between the extent of stent strut-adjacent inflammation, medial damage and restenosis in human ISR lesions studied in autopsy material excised at a mean of 10 months postimplantation. However, this autopsy study analyzed deep regions close to stent struts, irrespective of clinical or histological ISR, whereas our study is strictly confined to the upper parts of ISR neointima that had been ex vivo retrieved by directional atherectomy within symptomatic patients. Further evidence for a link between leukocytes and restenosis had been provided by previous work on atherectomy probes revealing a positive correlation between the macrophage number in atheroma at the time of angioplasty and subsequent propensity of restenosis [29]. However, other stud- ies that had analyzed ISR tissue at a late phase demonstrated only minimal inflammatory cells [4, 5], comparable to our present data. In addition, macrophage presence is further supported by low cell-bound CD40 and CRP expression levels within ISR lesions (fig. 1e, f).

Several possibilities could account for the apparent lack of both infection and inflammation in human ISR. Predisposition of primary atheroma devoid of pathogen burden/inflammation to develop ISR has not been supported by a broad body of literature [19, 30, 31]. Also, we demonstrate primary lesions to exhibit pronounced pathogen burden and to contain high levels of several inflammation-associated determinants. Therefore, inflammatory processes may not be basically implicated in late hyperplastic ISR or are widely completed with onset of clinical ISR. Thereby, our data may give another piece of evidence to the concept that apparently not mural smooth muscle cells, but other cell types such as bonemarrow-derived progenitor cells - devoid of infection - may participate in wound healing. Indeed, a few reports showed the presence of bone-marrow cells in solid neotinima $[6,32,33]$.

Another characteristic feature of human ISR was its pronounced hypercellularity (table 2) that significantly differed from primary lesion cell density, consistent with previous reports of others and our group [6, 23, 34]. Hypercellular neointima formation has been attributed to smooth muscle cell migration, proliferation and mitigated apoptosis [23, 34]. Likewise, in the present study, ISR tis- 
sue was predominantly composed of $\alpha$-SM actin-positive cells. However, ISR specimens contained no replicating cells, as indicated by the lack of Ki67 and PCNA labeling (fig. 3). This is supported by previous reports on restenotic atherectomy probes that demonstrated no or insignificant proliferation at the time of tissue removal $[4,31]$. Admittedly, our present findings differ from other reports that showed increased proliferative activity in post-balloon restenosis [22] and in human ISR samples [5, 35]. These contradictory results may be attributed to different time intervals between the first and second intervention, since most proliferative responses are completed within the first month post-vascular trauma [36]. Moreover, we now demonstrate that the incidence of programmed cell death in late ISR lesions is significantly reduced compared to primary atheroma (fig. 3), extending previous findings of our group that demonstrated mitigated apoptosis late, following balloon angioplasty [23]. Therefore, decreased apoptosis may be regarded as the key mechanism implicated in hypercellular neointima formation post-vascular trauma. Of course, any observation on human tissue obtained by atherectomy (1) is limited by reflecting only one single time point and (2) cannot examine early inflammatory and proliferative events known from longitudinal animal studies $[1,2,33]$. Although no significant relationship was found between the amount of the studied markers and several cardiovascular risk fac- tors and/or specific medications, the possibility that these determinants may have influence on the ISR formation by effects on vascular inflammation, proliferation and/or apoptosis, as reported by others $[37,38]$, cannot be definitively excluded.

Taken together, the present ex vivo study clearly demonstrates that (1) frequency of intimal pathogens (CMV, acute and chronic persistent chlamydial infection, HSV, EBV, HP) is low or insignificant, (2) presence of hHSP60, inflammatory cells or inflammatory markers is sparse, (3) pronounced hypercellularity in clinical ISR coincides with minimal cell replication and death levels, (4) all findings on human ISR were consistently independent of vascular origin and (5) apparently without time dependency after stent implantation. Our findings may contribute to better understand ISR and explain why antiinflammatory/antibiotic therapies for its prevention that had been suggested by animal models have not been successful so far in clinical practice.

\section{Acknowledgments}

The authors gratefully acknowledge the expert technical assistance of N. Kuhn and U. Rommerscheidt-Fuß. This work was supported in part by grants to G. B. of the Deutsche Forschungsgemeinschaft (DFG Ba 1076/2-2) and of the German Bundesministerium für Bildung und Forschung (project 01KV9915).

\section{References}

1 Lowe H, Oesterle SN, Khachigian LM: Coronary in-stent restenosis: Current status and future strategies. J Am Coll Cardiol 2002;39: 183-193.

2 Welt FGP, Rogers C: Inflammation and restenosis in the stent era. Arterioscler Thromb Vasc Biol 2002;22:1769-1776.

3 Ludewig B, Zinkernagel RM, Hengartner H: Arterial inflammation and atherosclerosis. Trends Cardiovasc Med 2002;12:154-159.

4 Chung I, Gold HK, Schwartz SM, Ikari Y, Reidy MA, Wight TN: Enhanced extracellular matrix accumulation in restenosis of coronary arteries after stent deployment. J Am Coll Cardiol 2002;40:2072-2081.

5 Moreno PR, Palacios IF, Leon MN, Rhodes J, Fuster V, Fallon JT: Histopathologic comparison of human coronary in-stent and post-balloon angioplasty restenotic tissue. Am J Cardiol 1999;84:462-466.

6 Skowasch D, Jabs A, Andrié R, Dinkelbach S, Lüderitz B, Bauriedel G: Presence of bonemarrow and neural-crest-derived cells in intimal hyperplasia at the time of clinical in-stent restenosis. Cardiovasc Res 2003;60:684-691.
7 Zohlnhöfer D, Klein CA, Richter T, Brandl R, Murr A, Nührenberg T, Schömig A, Baeuerle PA, Neumann FJ: Gene expression profiling of human stent-induced neointima by cDNA array analysis of microscopic specimens retrieved by helix cutter atherectomy. Detection of FK506-binding protein 12 upregulation. Circulation 2001;103:1396-1402.

8 Farb A, Sangiorgi G, Carter AJ, Walley VM, Edwards WD, Schwartz RS, Virmani R: Pathology of acute and chronic coronary stenting in humans. Circulation 1999;99:44-52.

9 Grewe PH, Deneke T, Machraoui A, Barmeyer J, Müller KM: Acute and chronic tissue response to coronary stent implantation: Pathologic findings in human specimen. J Am Coll Cardiol 2000;35:157-163.

10 Komatsu R, Ueda M, Naruko T, Kojima A, Becker AE: Neointimal tissue response at sites of coronary stenting in humans. Macroscopic, histological, and immunohistochemical analysis. Circulation 1998:98:224-233.
11 Kornowski R, Hong MK, Fermin OT, Bramwell $\mathrm{O}, \mathrm{Wu} \mathrm{H}$, Leon $\mathrm{MB}$ : In-stent restenosis: Contributions of inflammatory responses and arterial injury to neointimal hyperplasia. J Am Coll Cardiol 1998;31:224-230.

12 Piek JJ, van der Wal AC, Meuwissen M, Koch KT, Chamuleau SA, Teeling P, van der Loos $\mathrm{CM}$, Becker AE: Plaque inflammation in restenotic coronary lesions of patients with stable or unstable angina. J Am Coll Cardiol 2000;35: 963-967.

13 Farb A, Weber DK, Kolodgie FD, Burke AP, Virmani R: Morphological predictors of restenosis after coronary stenting in humans. Circulation 2002;105:2974-2980.

14 Epstein SE, Zhu J, Burnett MS, Zhou YF, Vercellotti G, Hahhar D: Infection and atherosclerosis. Potential roles of pathogen burden and molecular mimicry. Arterioscler Thromb Vasc Biol 2000;20:1417-1420.

15 Horne BD, Muhlestein JB, Strobel GG, Carlquist JF, Bair TL, Anderson JL: Greater pathogen burden but not elevated C-reactive protein increases the risk of clinical restenosis after percutaneous coronary intervention. Am Heart J 2002;144:491-500. 
16 Neumann FJ, Kastrati A, Miethke T, Mehilli J, Pogatsa-Murray G, Koch W, Seyfarth M, Schömig A: Previous cytomegalovirus infection and restenosis after coronary stent placement. Circulation 2001;104:1135-1139.

17 Neumann FJ, Kastrati A, Miethke T, PogatsaMurray G, Mehilli J, Valina C, Jogethaei N, da Costa CP, Wagner H, Schömig A: Treatment of Chlamydia pneumoniae infection with roxithromycin and effect on neointima proliferation after coronary stent placement (ISAR-3): A randomized, double blind, placebo-controlled trial. Lancet 2001;357:2085-2089.

18 Saikku P, Leinonen M, Mattila K, Ekman MR, Nieminen MS, Makela PH, Huttunen JK, Valtonen V: Serological evidence of an association of a novel Chlamydia, TWAR, with chronic coronary heart disease and acute myocardial infarction. Lancet 1988;2:983-986.

19 Zhou YF, Leon MB, Waclawiw MA, Popma JJ, Yu ZX, Finkel T, Epstein SE: Association between prior cytomegalovirus infection and the risk of restenosis after coronary atherectomy. $\mathrm{N}$ Engl J Med 1996;335:624-630.

20 Mayr M, Kiechl S, Willeit J, Wick J, Xu Q: Infections, immunity, and atherosclerosis. Associations of antibodies to Chlamydia pneumoniae, Helicobacter pylori, and cytomegalovirus with immune reactions to heat-shock protein 60 and carotid or femoral atherosclerosis. Circulation 2000;102:833-839.

21 O'Brien ER, Alpers CE, Stewart DK, Ferguson M, Tran N, Gordon D, Benditt EP, Hinohara T, Simpson JB, Schwartz SM: Proliferation in primary and restenotic coronary atherectomy tissue: Implications for antiproliferative therapy. Circ Res 1993;73:223-231.

22 Pickering JG, Weir L, Jekanowsk J, Kearny MA, Isner JM: Proliferative activity in peripheral and coronary atherosclerotic plaque among patients undergoing percutaneous revascularization. J Clin Invest 1993;91:1469_ 1480 .
23 Bauriedel G, Schluckebier S, Hutter R, Welsch U, Kandolf R, Lüderitz B, Prescott MF: Apoptosis in restenosis versus stable-angina atherosclerosis: Implications for the pathogenesis of restenosis. Arterioscler Thromb Vasc Biol 1998;18:1132-1139.

24 Abdelmegui AE, Ellis SG, Sapp SK, Simpendorfer C, Franco I, Whitlow PL: Directional atherectomy in unstable angina. J Am Coll Cardiol 1994;24:46-54.

25 Simonton CA, Leon MB, Baim DS, Hinohara T, Kent KM, Bersin RM, Wilson BH, Mintz GS, Fitzgerald PJ, Yock PG, Popma JJ, Ho KK, Cutlip DE, Senerchia C, Kuntz RE: Optimal directional coronary atherectomy. Final results of the optimal atherectomy restenosis study (OARS). Circulation 1998;97:332-339.

26 Kol A, Bourcier T, Lichtman AH, Libby P: Chlamydial and human heat shock protein $60 \mathrm{~s}$ activate human vascular endothelium, smooth muscle cells, and macrophages. J Clin Invest 1999; 103:571-577.

27 Chiu B: Multiple infections in carotid atherosclerotic plaque. Am Heart J 1999;138:S534S536.

28 Arbustini E, De Servi S, Bramucci E, Porcu E, Costante AM, Grasso M, Diegoli M, Fasani R, Morbini P, Angoli L: Comparison of coronary lesions obtained by directional coronary atherectomy in unstable angina, stable angina and restenosis after either atherectomy or angioplasty. Am J Cardiol 1995;75:675-682.

29 Moreno PR, Bernardi VH, Lopez-Cuellar J, Newell JB, McMellon C, Gold HK, Palacios IF, Fuster V, Fallon JT: Macrophage infiltration predicts restenosis after coronary intervention in patients with unstable angina. Circulation 1996;94:3098-3102
30 Buffon A, Liuzzo G, Biasucci LM, Pasqualetti P, Ramazzotti V, Rebuzzi AG, Crea F, Maseri A: Preprocedural serum levels of C-reactive protein predict early complications and late restenosis after coronary angioplasty. J Am Coll Cardiol 1999;34:1512-1521.

31 Lutgens E, Daemen JAP: CD40-CD40L interactions in atherosclerosis. Trends Cardiovasc Med 2002;12:27-32.

32 Han CL, Campbell GR, Campbell JH: Circulating bone marrow cells can contribute to neointimal formation. J Vasc Res 2001;38: 113-119.

33 Bauriedel G, Jabs A, Skowasch D, Hutter R Badimon JJ, Fuster V, Welsch U, Lüderitz B: Dendritic cells in neointima formation after rat carotid balloon injury. Coordinated expression with anti-apoptotic Bcl-2 and HSP47 in arterial repair. J Am Coll Cardiol 2003;42:930-938.

34 Bauriedel G, Schmücking I, Schmidt T, Braun P, Park JW, Heinrich KW, Lüderitz B: Intimal cell density in postangioplasty versus primary coronary and peripheral lesions: A systematic study on human atherectomy samples. J Interven Cardiol 1997;10:417-425.

35 Kearney M, Pieczek A, Haley L, Losordo DW Andres V, Schainfeld R, Rosenfield K, Isner JM: Histopathology of in-stent restenosis in patients with peripheral artery disease. Circulation 1997;95:1998-2002.

36 Carter AJ, Laird JR, Farb A, Kufs W, Wortham DC, Virmani R: Morphologic characteristics of lesion formation in a porcine proliferative restenosis model. J Am Coll Cardiol 1994; 24:1398-1405.

37 Schönbeck U, Libby P: Inflammation, immunity, and $\mathrm{HMG}-\mathrm{CoA}$ reductase inhibitors. Statins as anti-inflammatory agents? Circulation 2004;109(suppl II):II-18-II-26.

38 Lévy BI: Can angiotensin II type 2 receptors have deleterious effects in cardiovascular disease? Implications for therapeutic blockade of the rennin-angiotensin system. Circulation 2004;109:8-13. 